\title{
Cyclic Organoselenide BODIPY-Based Probe: Targeting Superoxide in MCF-7 Cancer Cells
}

Kashinath S. Madibone, Pratiksha P. Deshmukh, Ambuja Navalkar, Samir K. Maji, Purav M. Badani and Sudesh T. Manjare*

\section{Content}

Experimental details.......................................... 2

Synthesis and characterization.................................... 18

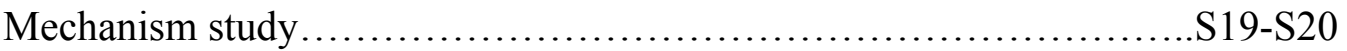

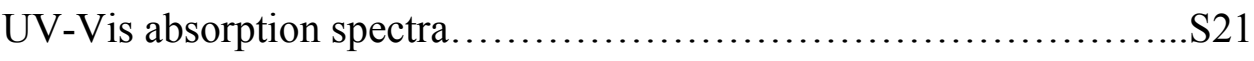

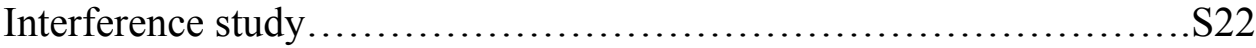

Detection limit study............................................. 22

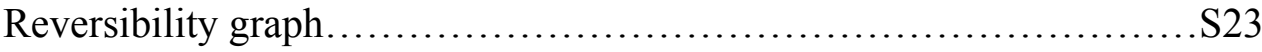

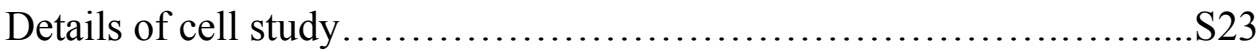




\section{Synthesis and Characterization}

\section{Synthesis of Naphthalene-1,8-diselenide:}

Naphthalene (1.5 g, $12.015 \mathrm{mmol})$ was stirred with $18 \mathrm{~mL}$ of hexane containing (48 mmol, $30 \mathrm{ml})$ n-butyllithium and TMEDA $(7.2 \mathrm{ml}, 24 \mathrm{mmol})$ at $60{ }^{\circ} \mathrm{C}$ for 3 hours. The resulting suspension of the lithio-derivative was allowed to cool to $-78{ }^{\circ} \mathrm{C}$ and was diluted with $50 \mathrm{ml}$ of THF and selenium (3.792 g, $48 \mathrm{mmol}$ ), was added to the suspension. The resulting orange mixture was warmed to $25{ }^{\circ} \mathrm{C}$ and allowed to stir it for 12 hours. The reaction was monitored by TLC. The reaction was quenched with $10 \mathrm{ml}$ of water and extract with chloroform. The organic layer was dried over anhydrous $\mathrm{Na}_{2} \mathrm{SO}_{4}$. The dark brown crude liquid was purified using column chromatography (pet ether) which gave dark brown solid. The yield of purified product was $3.413 \mathrm{~g}(28 \%)$.
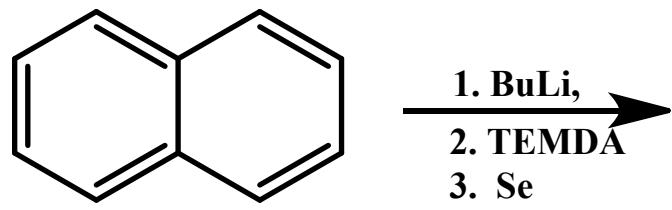

THF

Scheme S1. Synthesis of naphthalene-1,8-diselenide

\section{Synthesis of Naphthalene1,8-diselenide,2-carboxaldehyde:}

This compound was synthesized by Vilsmeier-Haack formylation. The $0.9 \mathrm{~mL}$ of $\mathrm{POCl}_{3}$ (1.53 g, $10.03 \mathrm{mmol})$ was added dropwise to the stirred solution of Naphthalene-1,8diselenide $(0.75 \mathrm{~g}, 2.64 \mathrm{mmol})$ in dry DMF $(7.5 \mathrm{~mL})$ at $0{ }^{0} \mathrm{C}$ under nitrogen atmosphere. Further, reaction mixture was allowed to come to room temperature and reaction was continued till 24 hoursunder nitrogen condition. To the reaction mixture, water was added which yielded yellow solid. The crude compound was extracted with ethyl acetate and water. The organic layer was dried over $\mathrm{Na}_{2} \mathrm{SO}_{4}$ and the solvent was evaporated under reduced pressure. The desired product was purified by column chromatography (pet ether) which gave dark brown solid. The yield of product was $0.553 \mathrm{~g}(67 \%)$. 


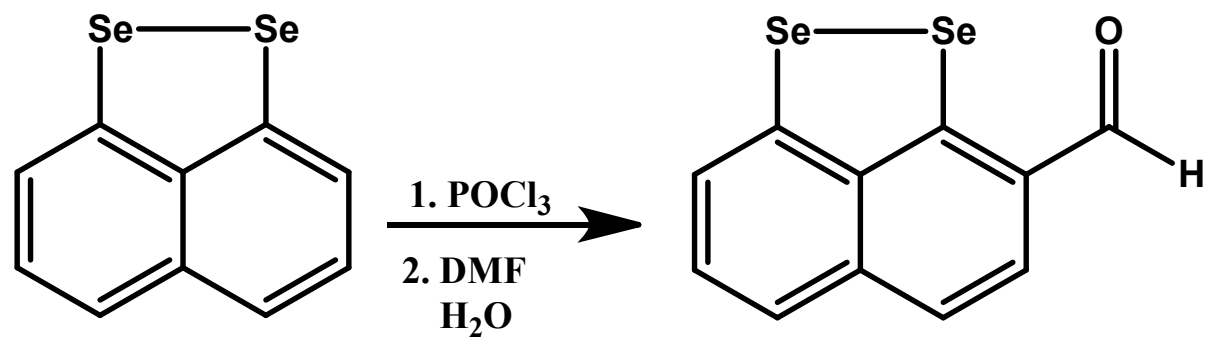

Scheme S2. Synthesis of Naphthalene1,8-diselenide,2-carboxaldehyde

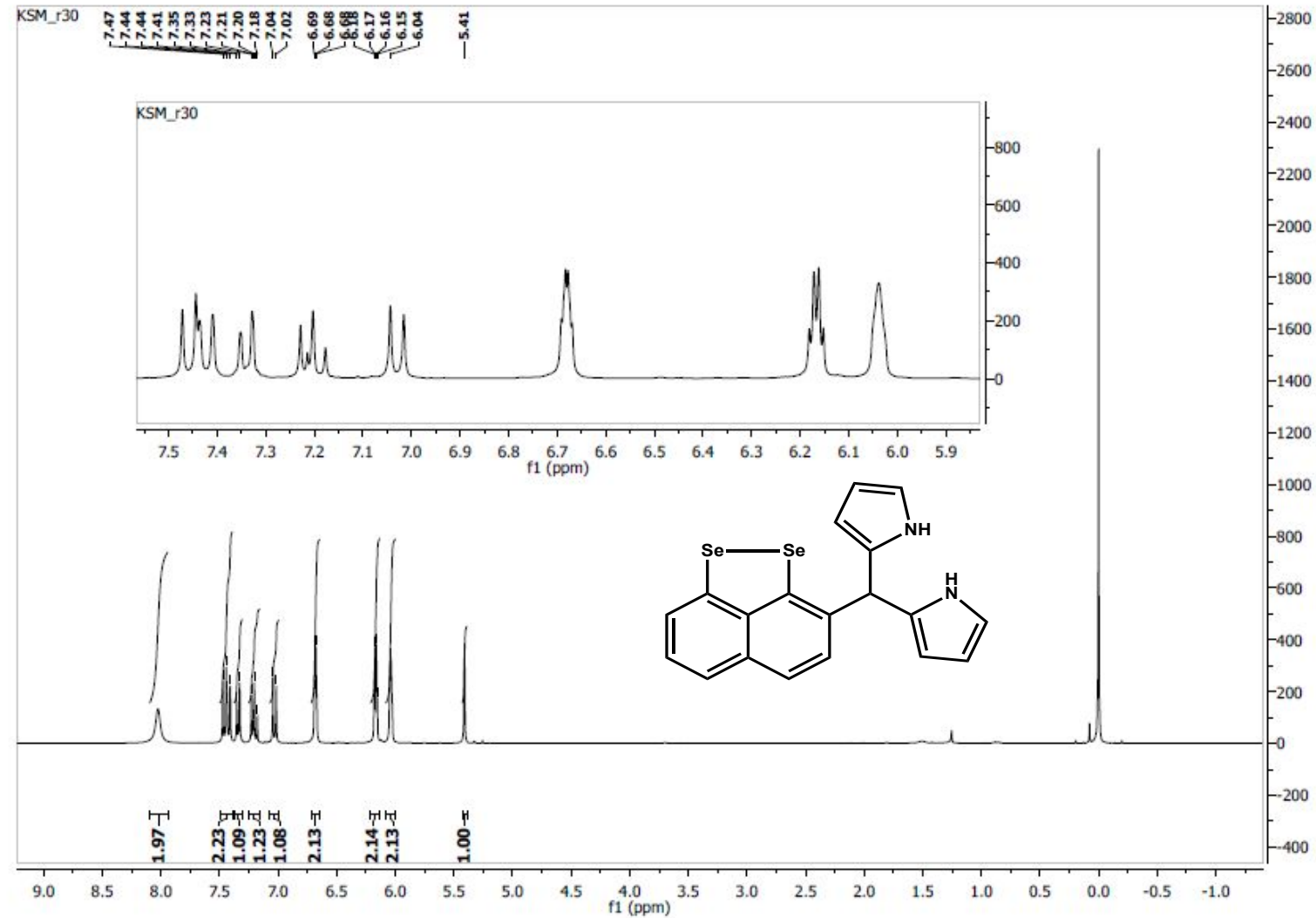

Figure S1. ${ }^{1} \mathrm{H}$ NMR spectrum of 2 . 


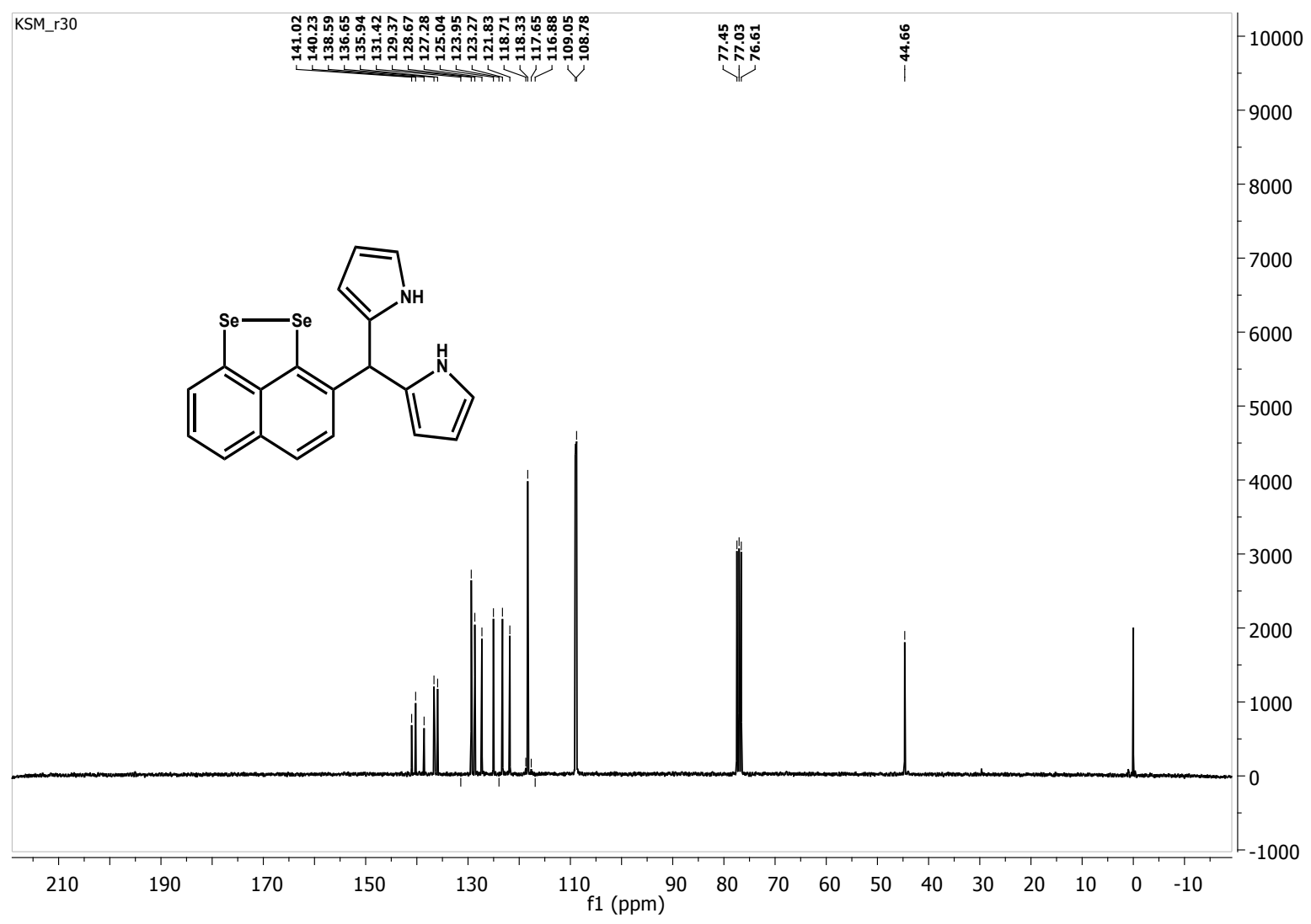

Figure S2. ${ }^{13} \mathrm{C}$ NMR spectrum of 2. 


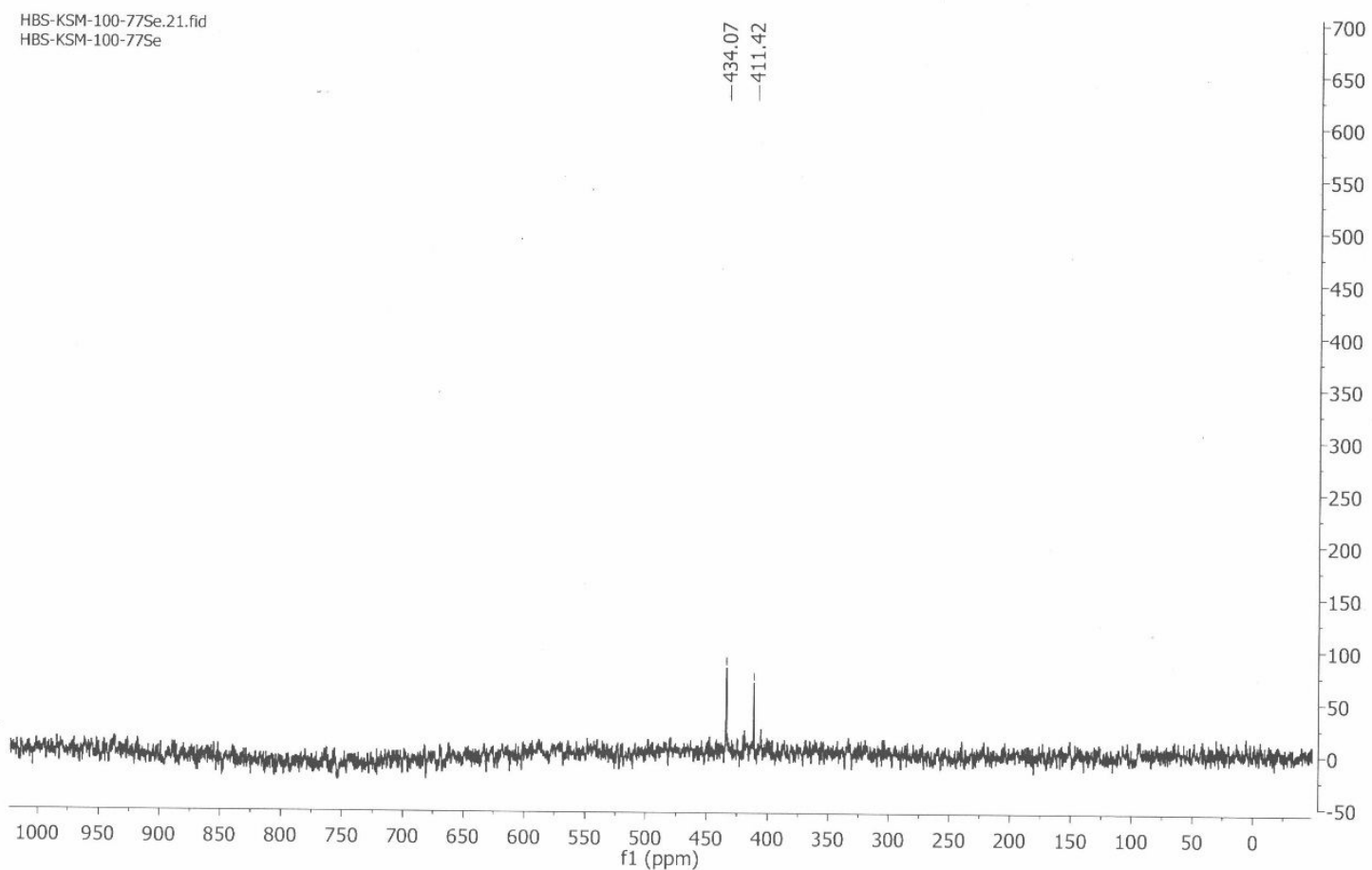

Figure S3. Expanded ${ }^{77} \mathrm{Se}$ NMR spectrum of 2.

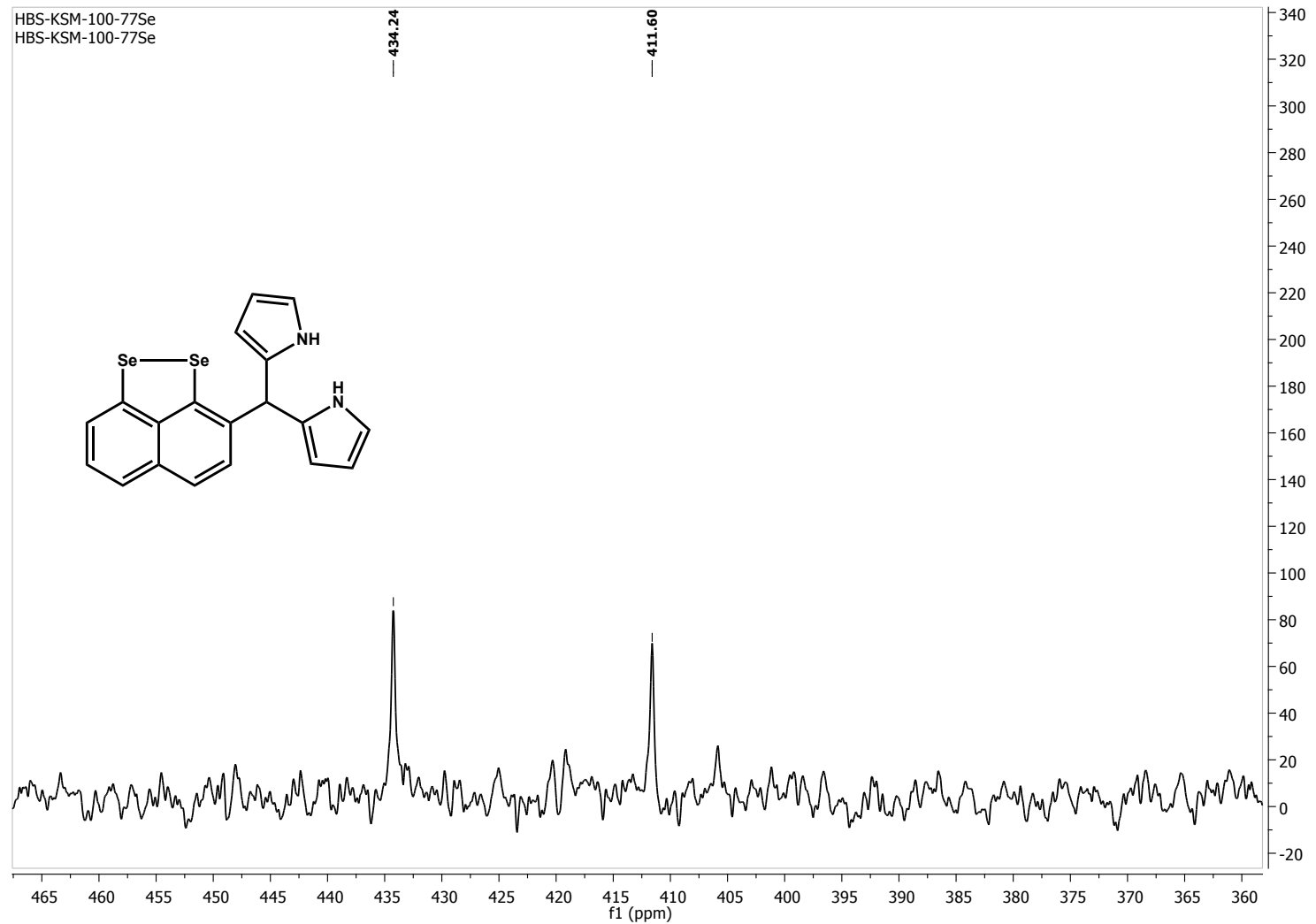

Figure S4. Expanded ${ }^{77} \mathrm{Se}$ NMR spectrum of 2. 


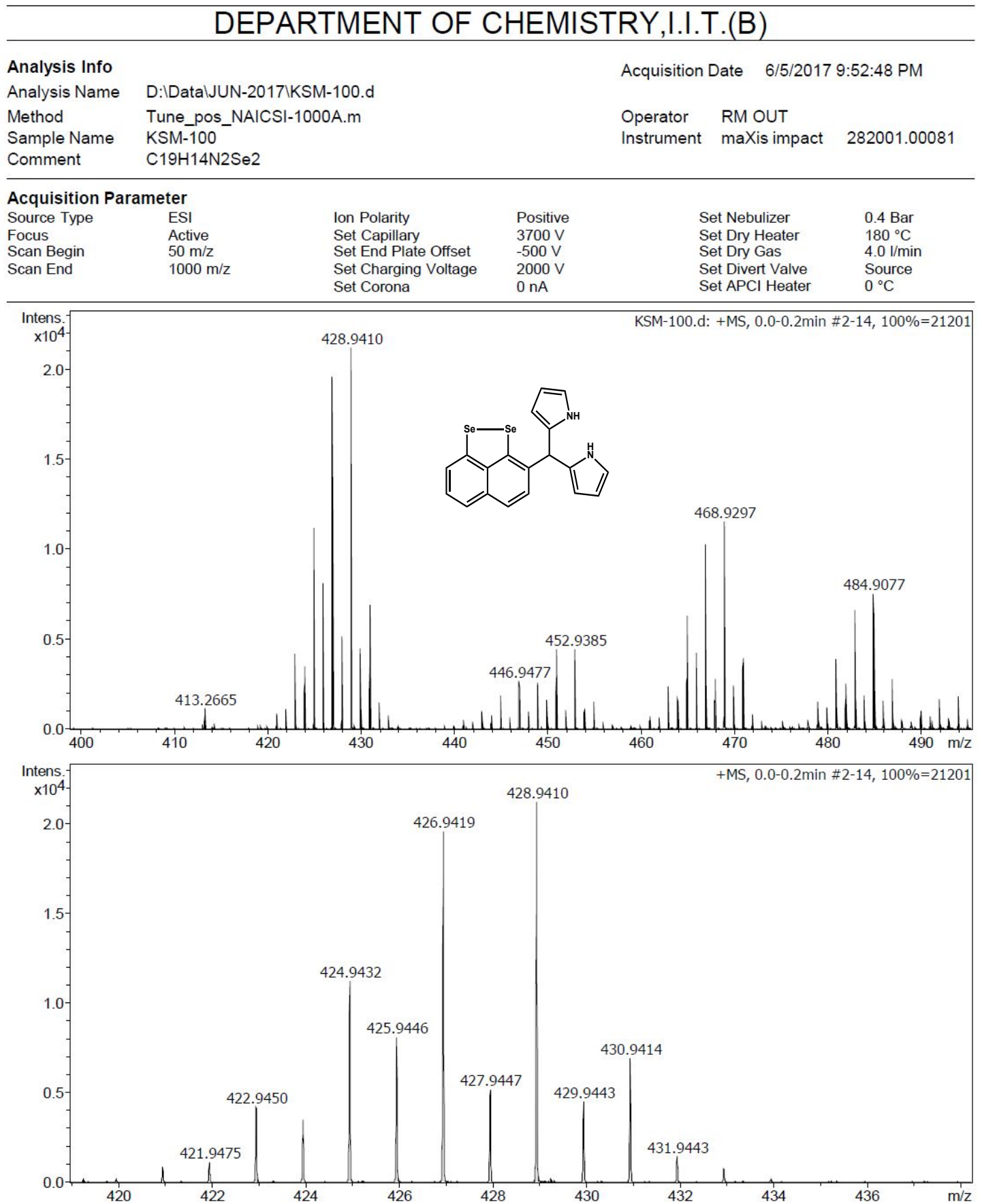

KSM-100.d

Bruker Compass DataAnalysis 4.1 $\quad$ printed: 6/19/2017 10:07:56 PM by: DM OUT

Figure S5. Mass spectrum of 2. 


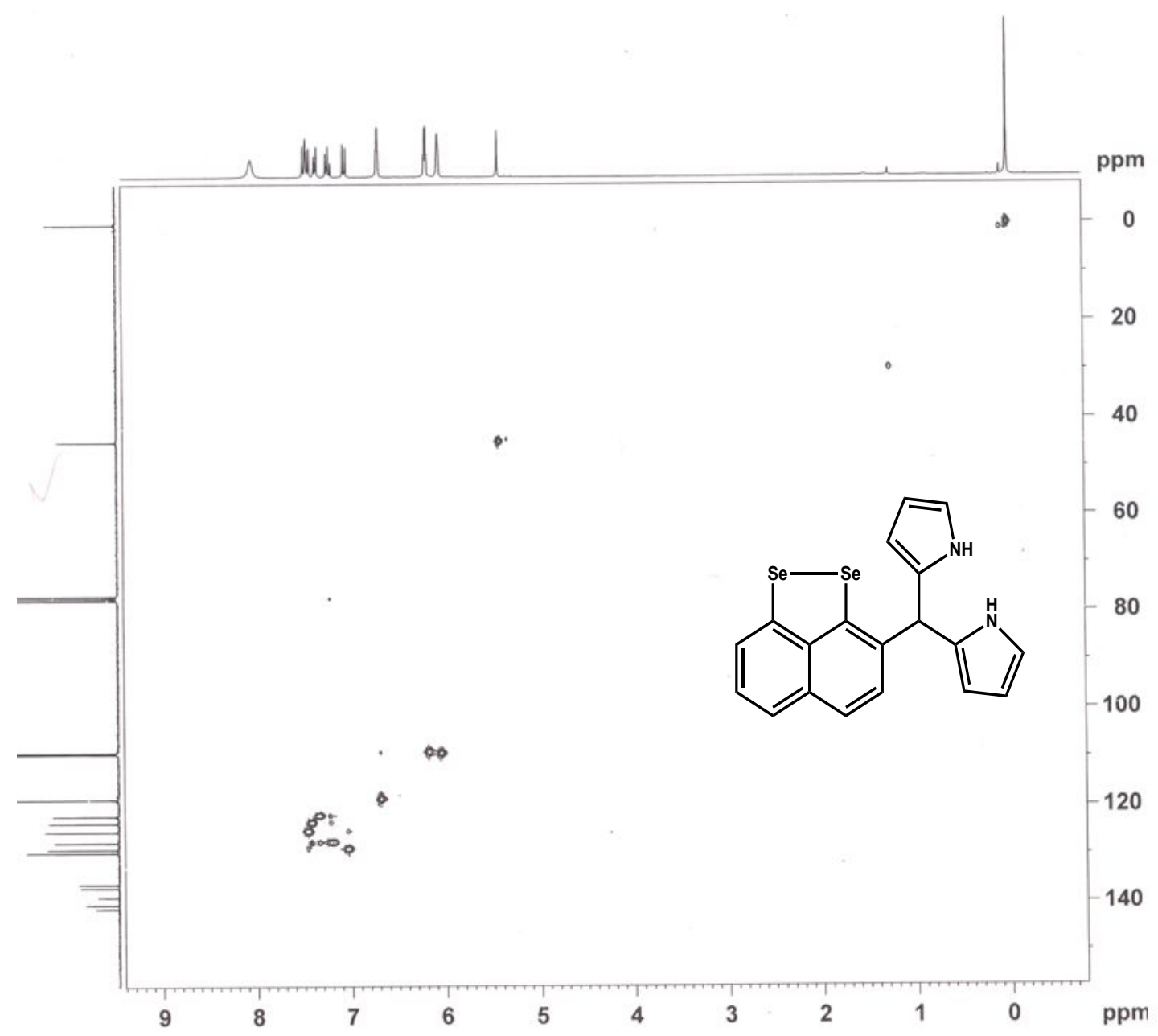

Figure S6. ${ }^{1} \mathrm{H}-{ }^{13} \mathrm{C}$ HSQC NMR spectrum of 2. 


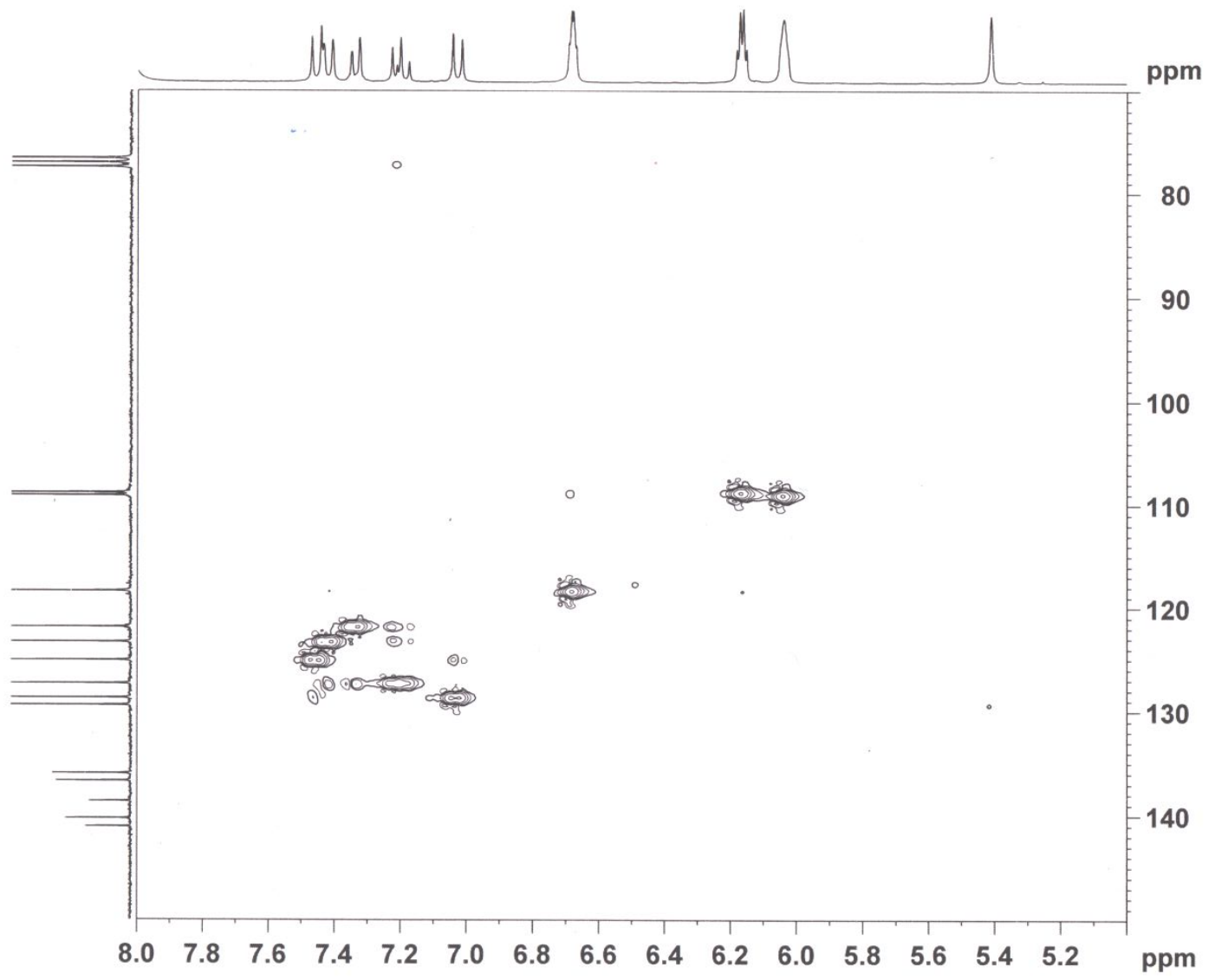

Figure S7. Expanded ${ }^{1} \mathrm{H}-{ }^{13} \mathrm{C}$ HSQC NMR spectrum of 2. 


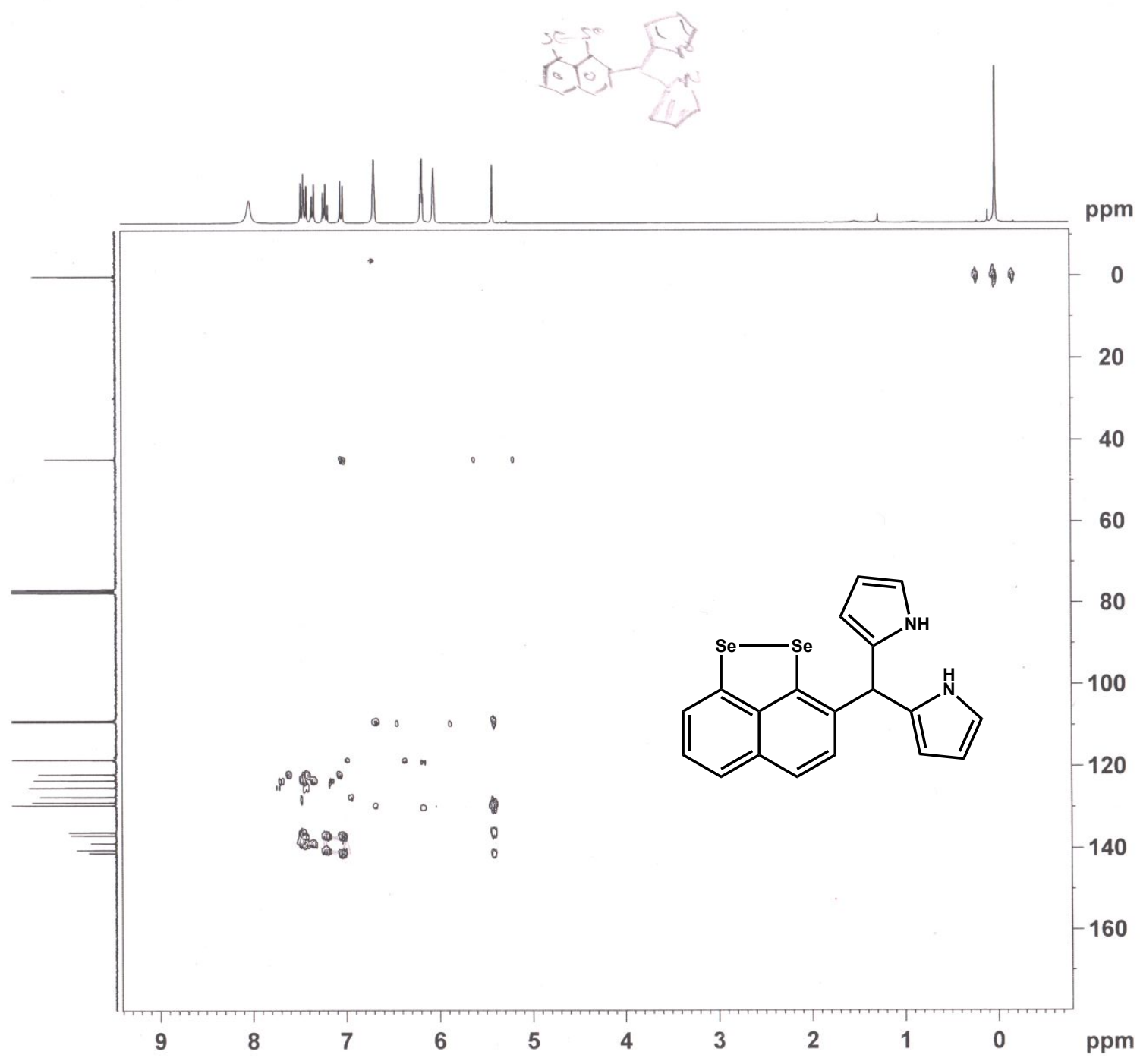

Figure S8. ${ }^{1} \mathrm{H}-{ }^{13} \mathrm{C}$ HMBC NMR spectrum of 2. 


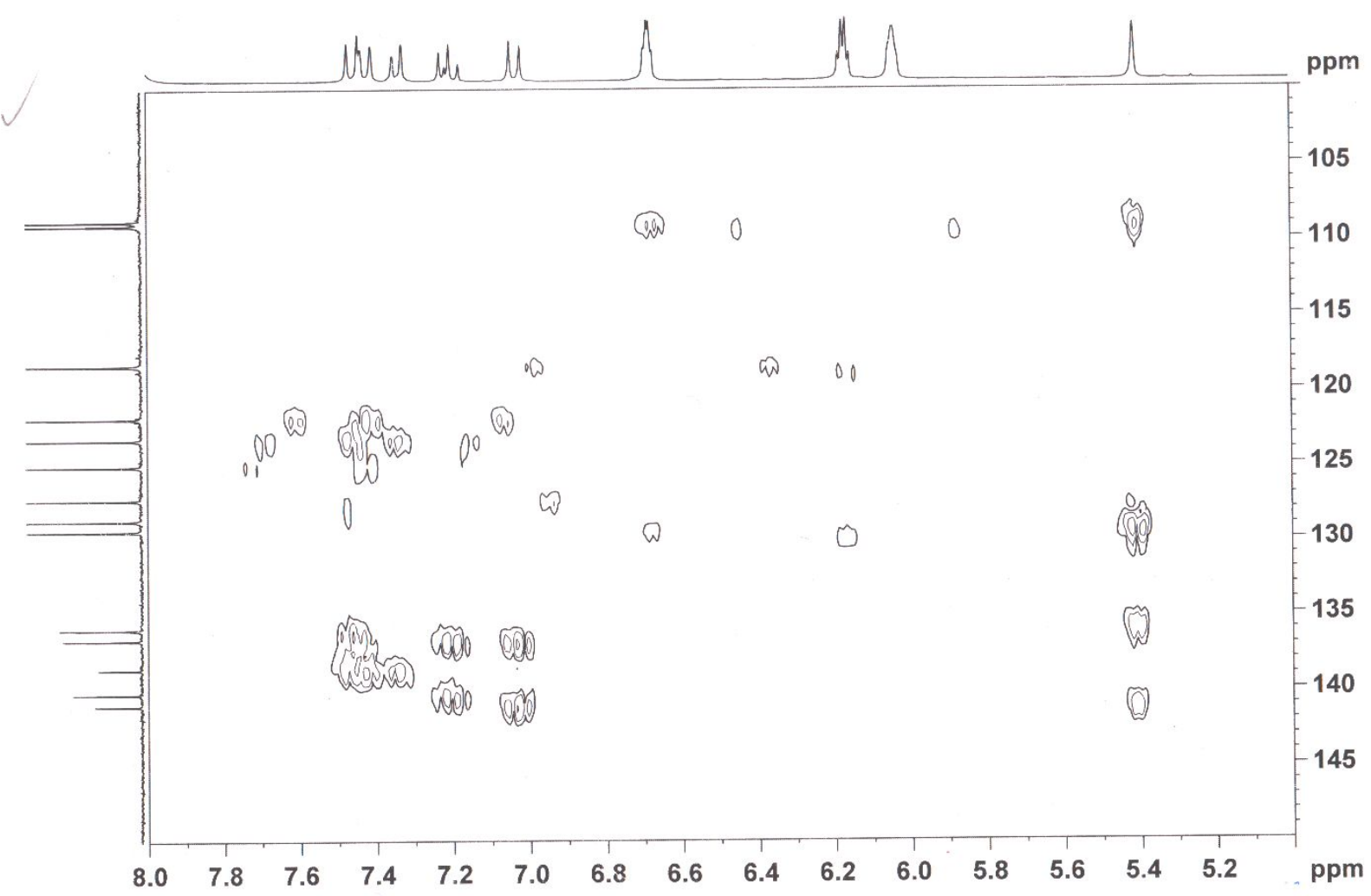

FigureS9. Expanded ${ }^{1} \mathrm{H}-{ }^{13} \mathrm{C}$ HMBC NMR spectrum of 2.

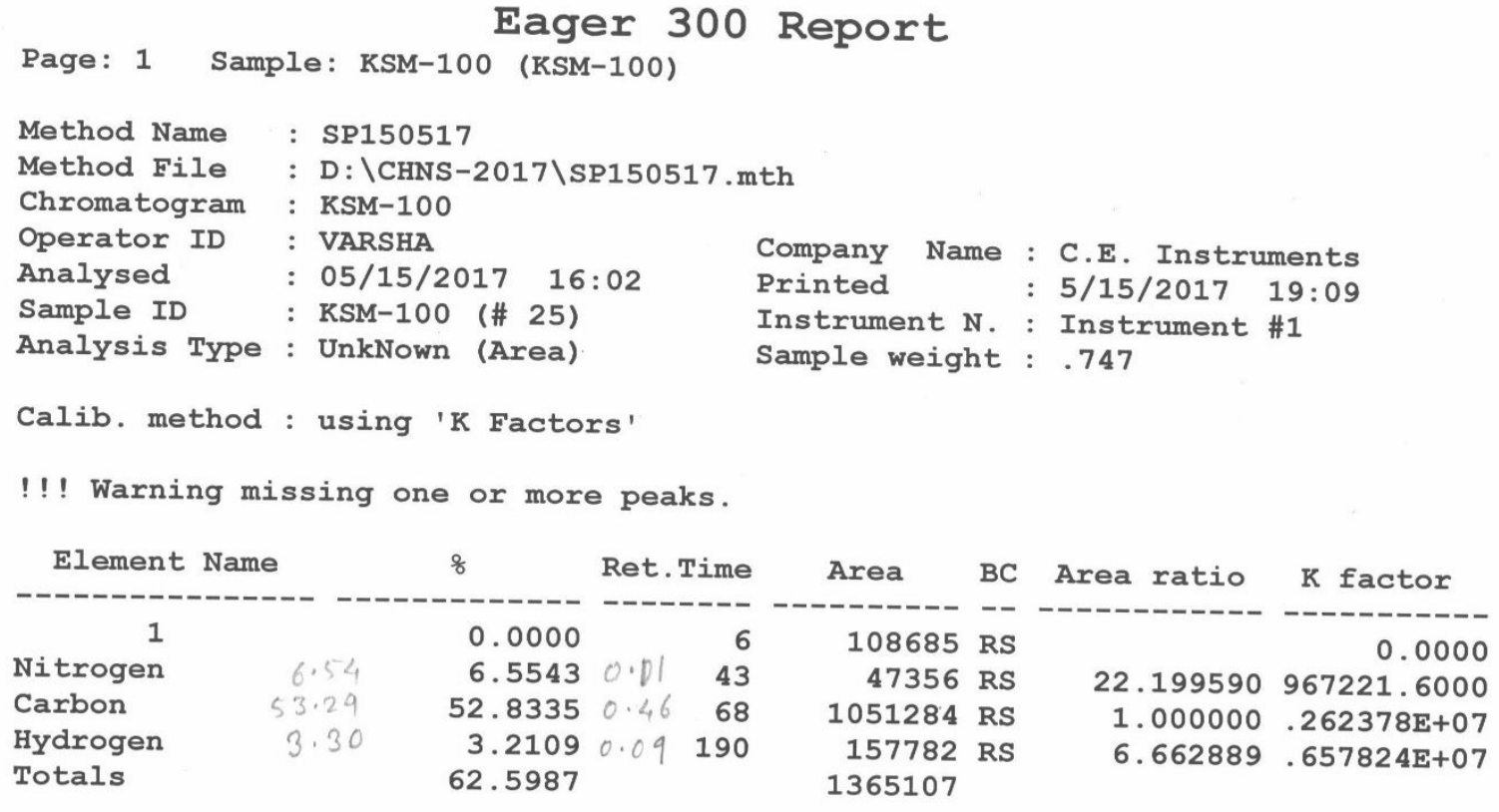

Figure S10. Elemental analysis of 2. 


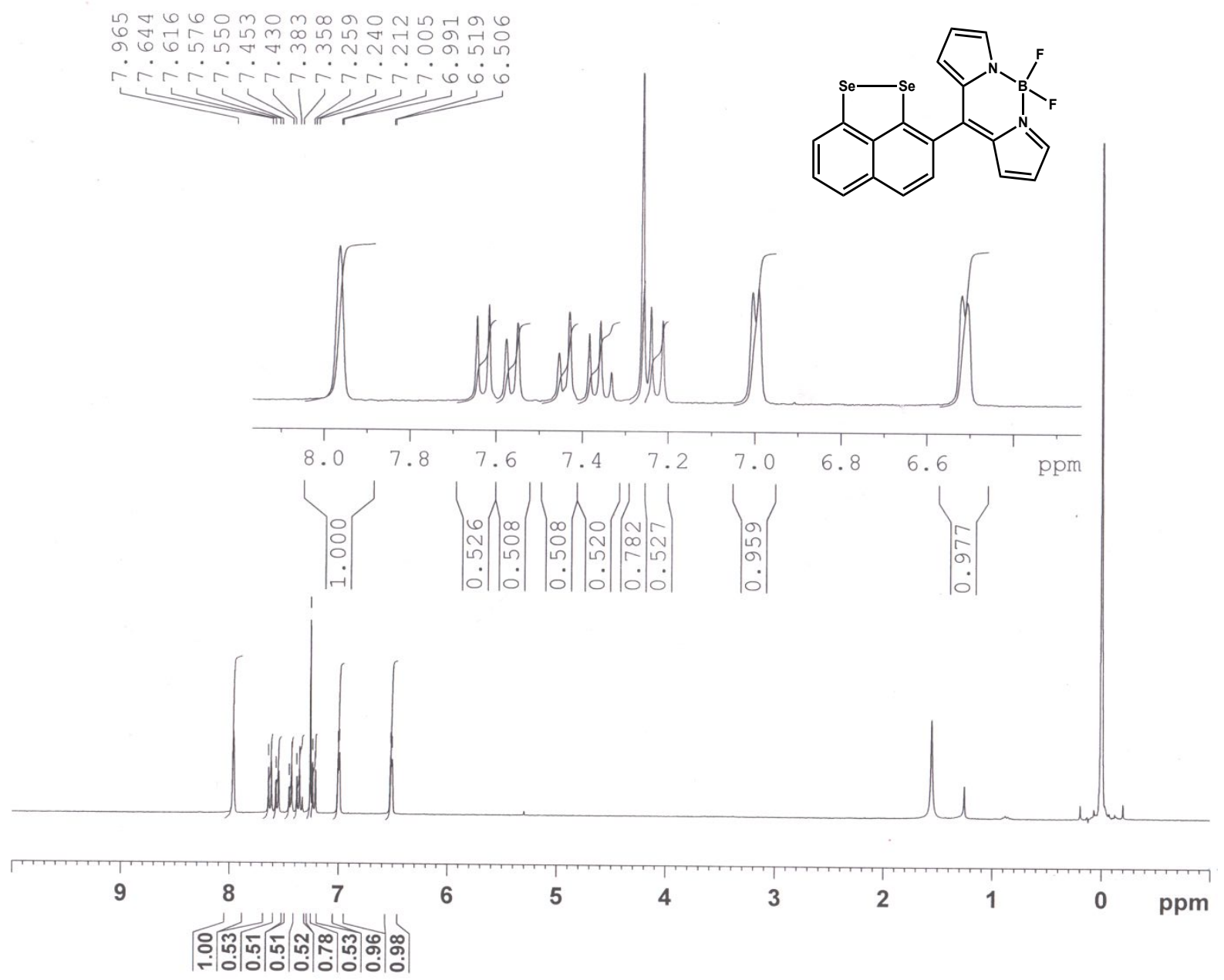

Figure S11. ${ }^{1} \mathrm{H}$ NMR spectrum of 3 . 


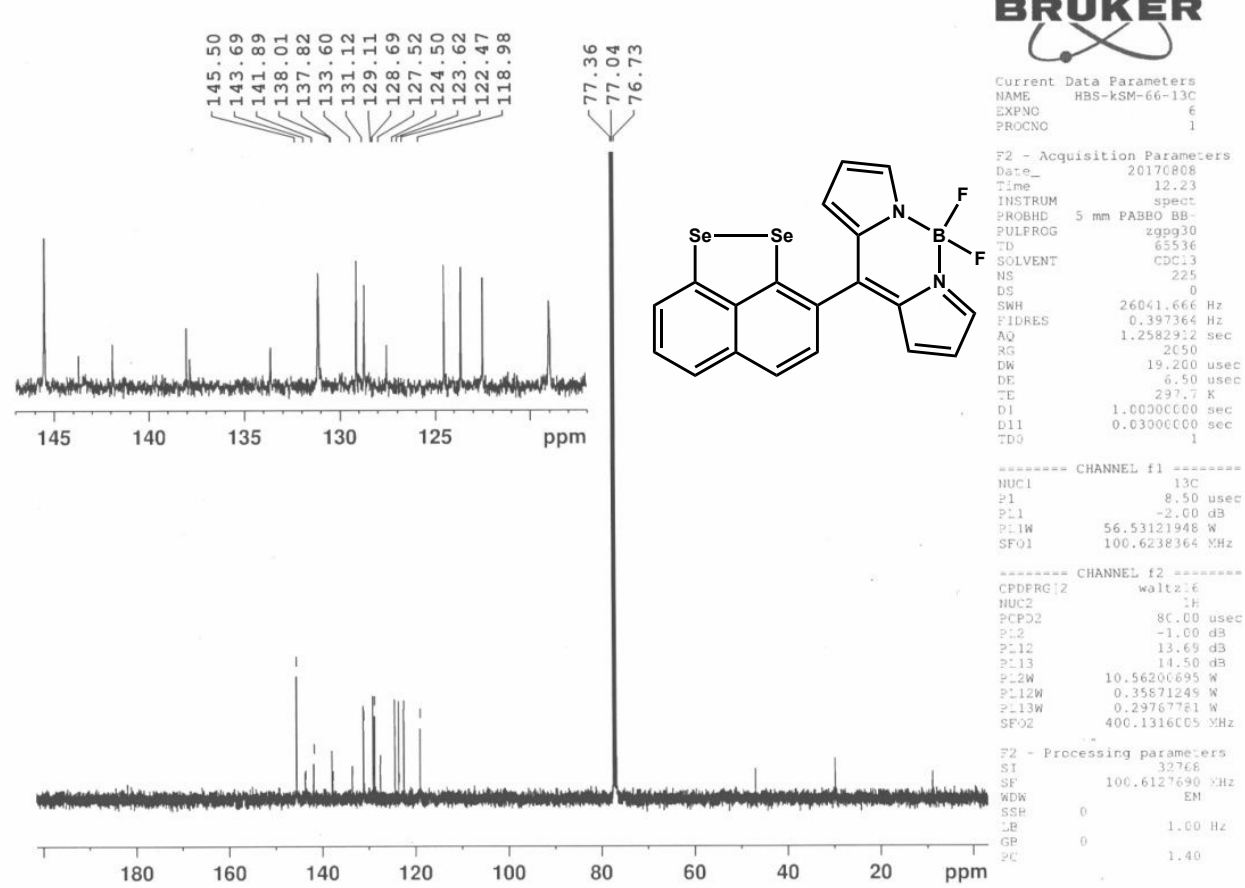

Figure S12. ${ }^{13} \mathrm{C}$ NMR spectrum of 3 . 


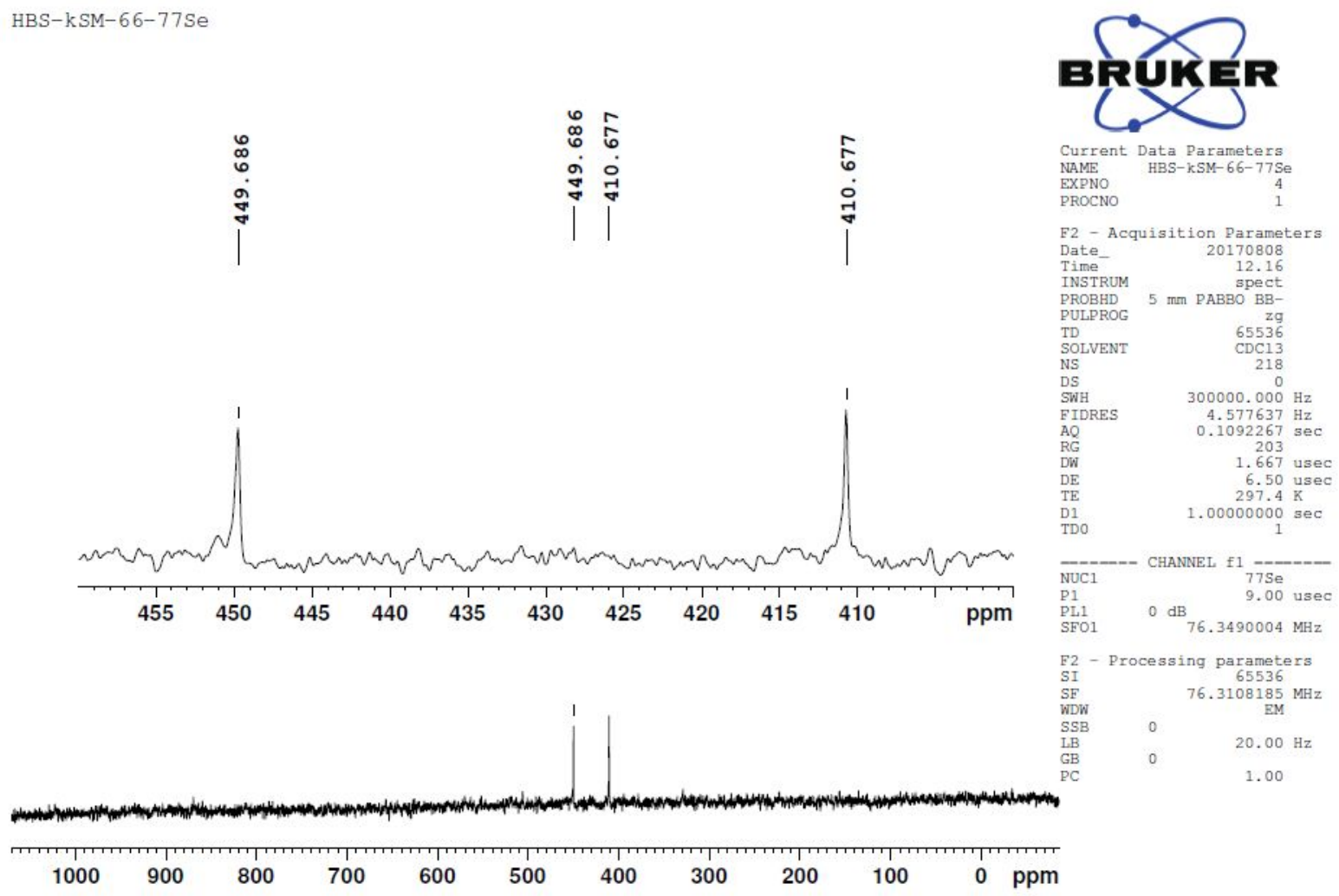

Figure S13. ${ }^{77} \mathrm{Se}$ NMR spectrum of 3.

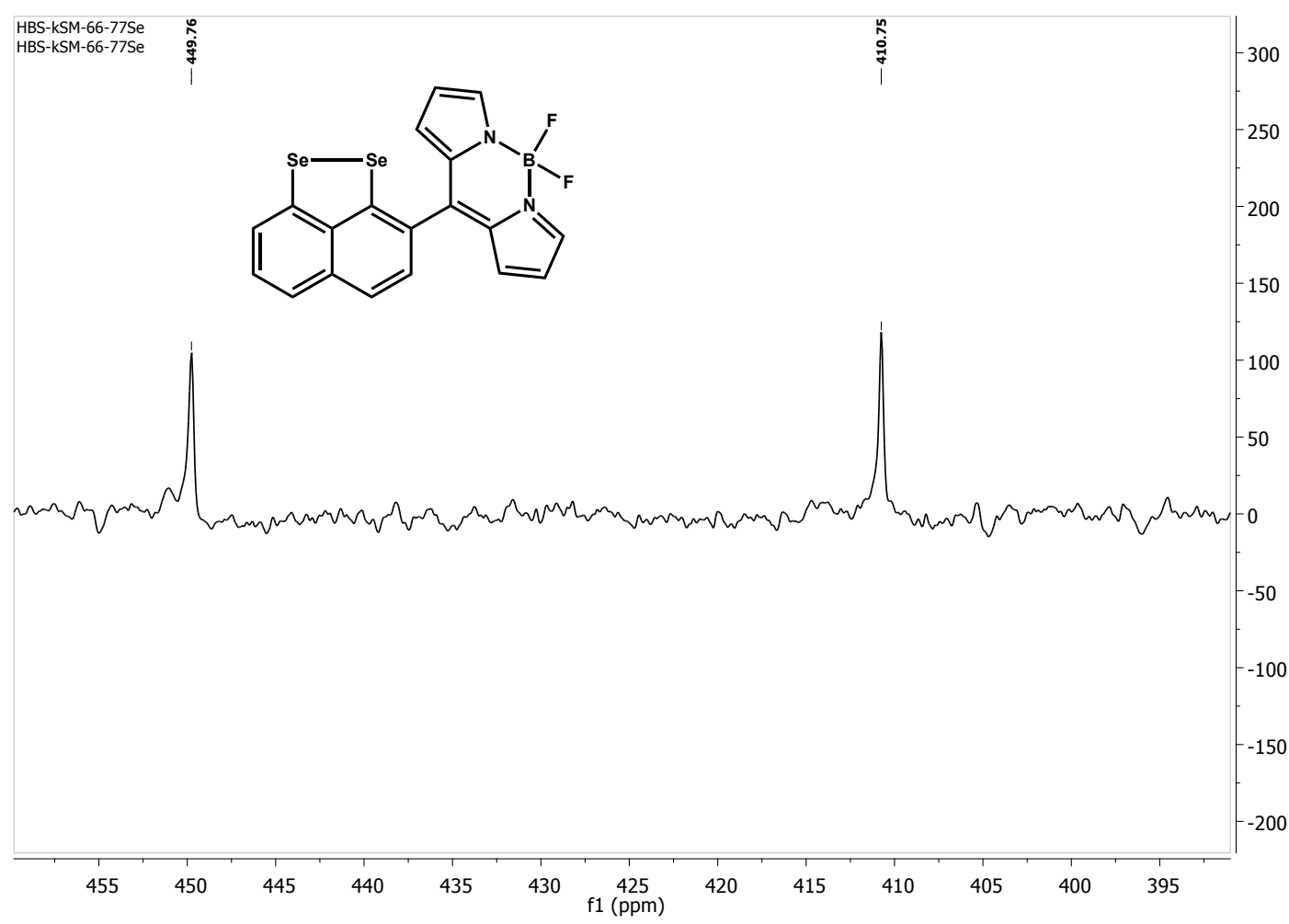

Figure S14. Expanded ${ }^{77} \mathrm{Se}$ NMR spectrum of $\mathbf{3}$ 


\section{DEPARTMENT OF CHEMISTRY,I.I.T.(B)}

\section{Analysis Info}

Analysis Name

Method

Sample Name

Comment
D:IDatalJUN-2017\KSM-83..d

Tune_pos_NAICSI-1000A.m

KSM-83.

$\mathrm{C} 19 \mathrm{H} 11 \mathrm{~N} 2 \mathrm{BF} 2 \mathrm{Se} 2$
Acquisition Date 6/5/2017 9:37:57 PM

Operator RM OUT

Instrument maXis impact $\quad 282001.00081$

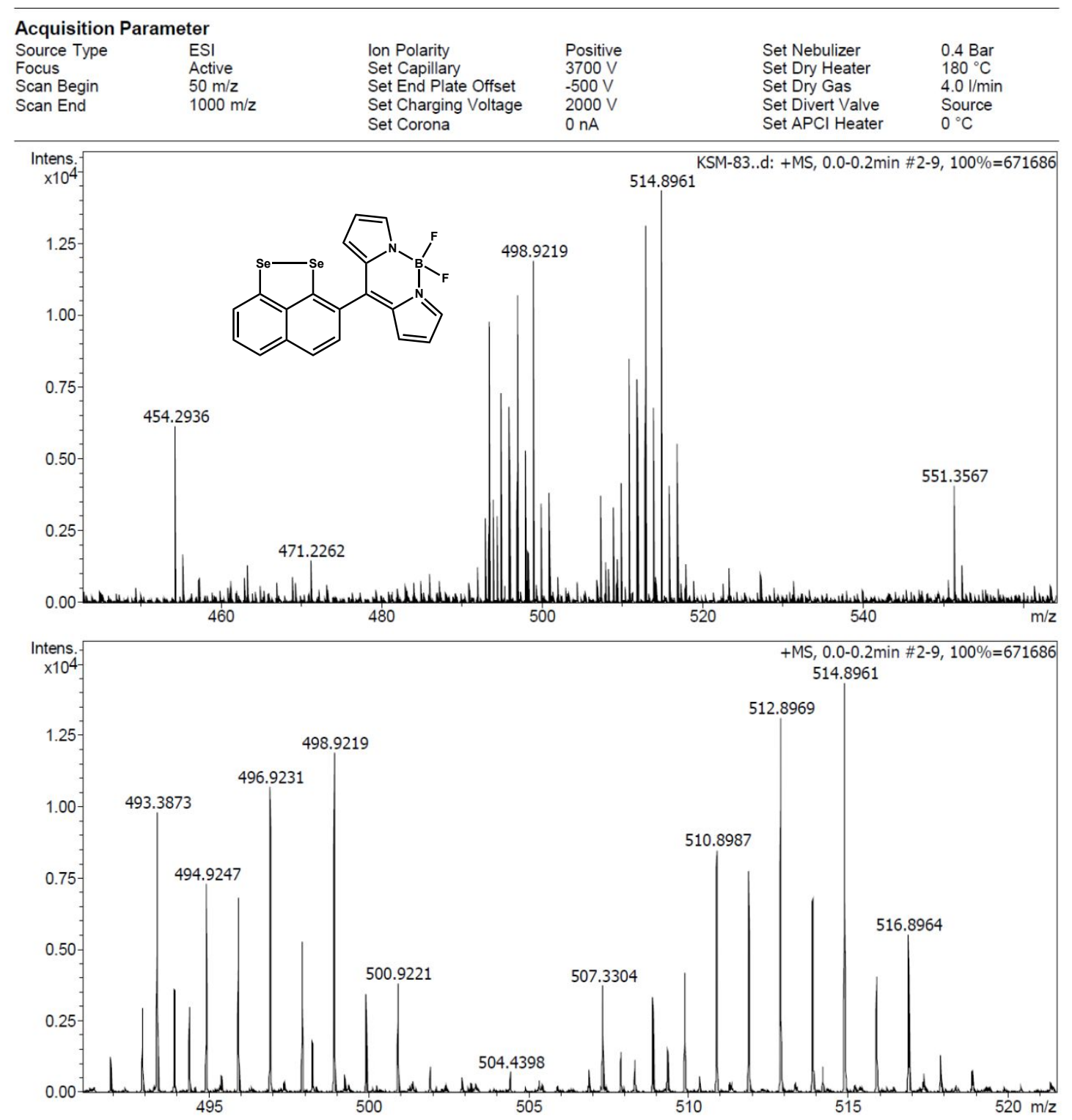

KSM-83..d

Bruker Compass DataAnalysis 4.1 printed: 6/19/2017 10:13:21 PM

Figure S15. Mass spectrum of 3 . 


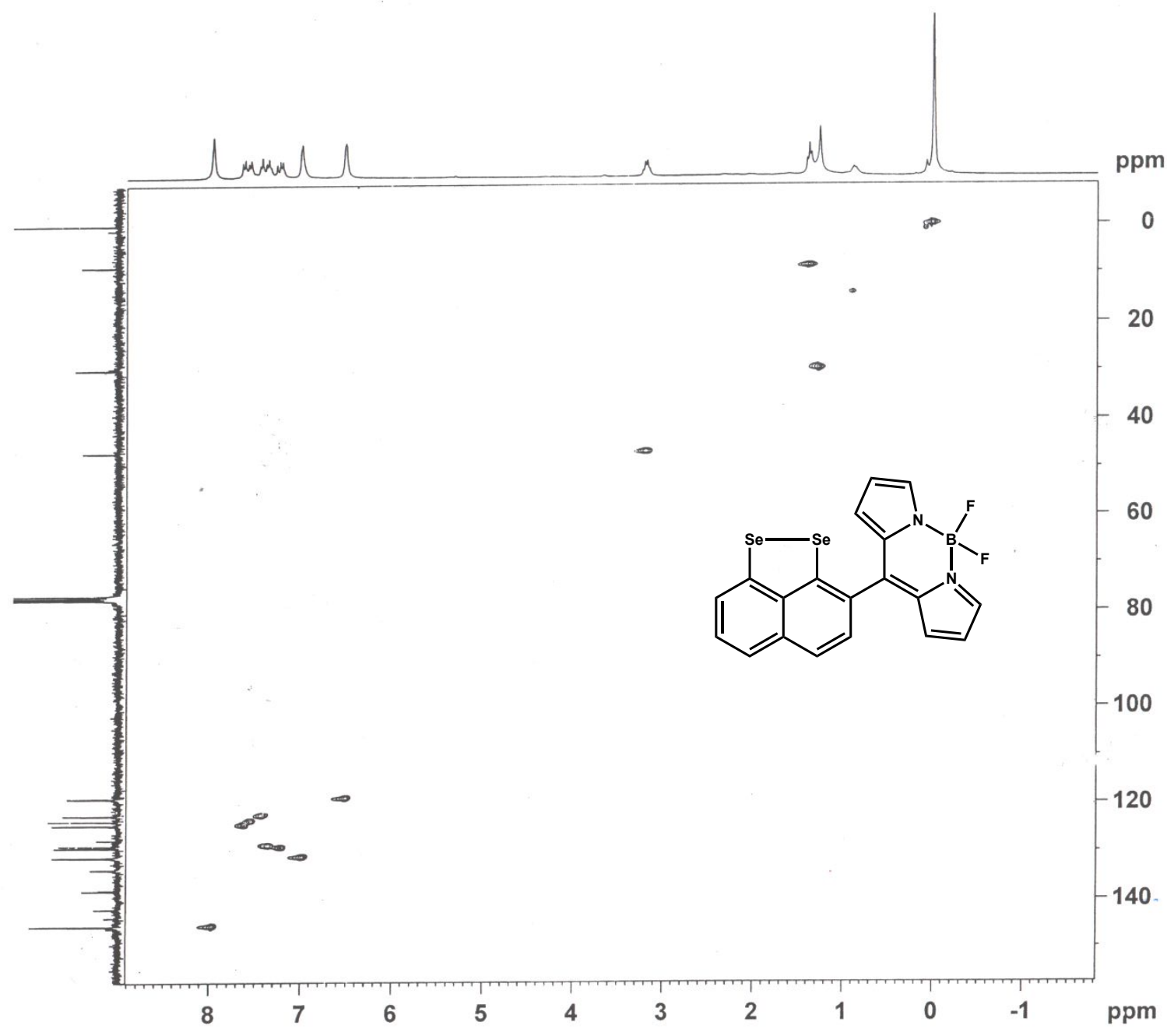

Figure S16. ${ }^{1} \mathrm{H}-{ }^{13} \mathrm{C}$ HSQC NMR spectrum of 3. 


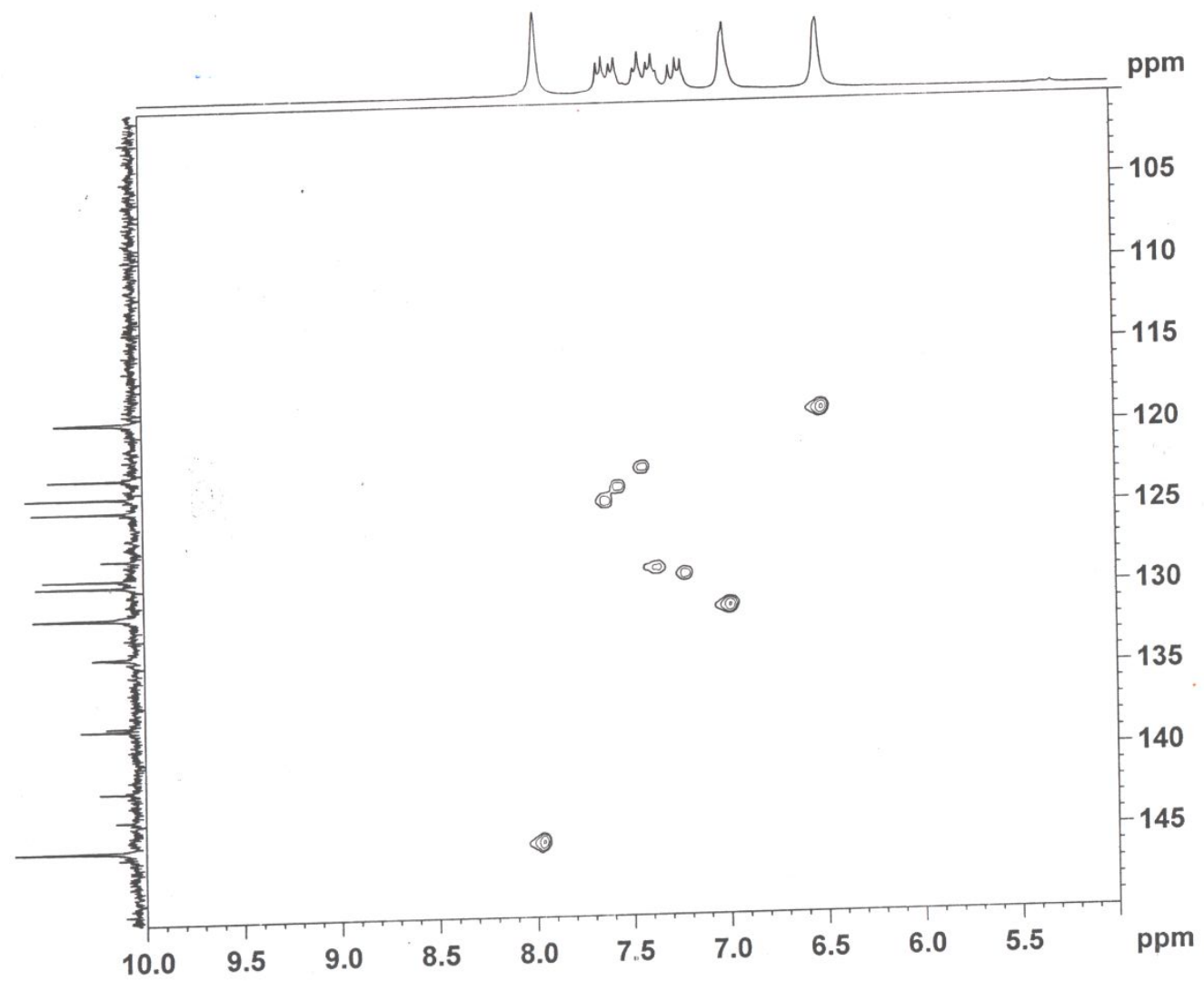

Figure S17. Expanded ${ }^{1} \mathrm{H}-{ }^{13} \mathrm{C}$ HSQC NMR spectrum of 3. 


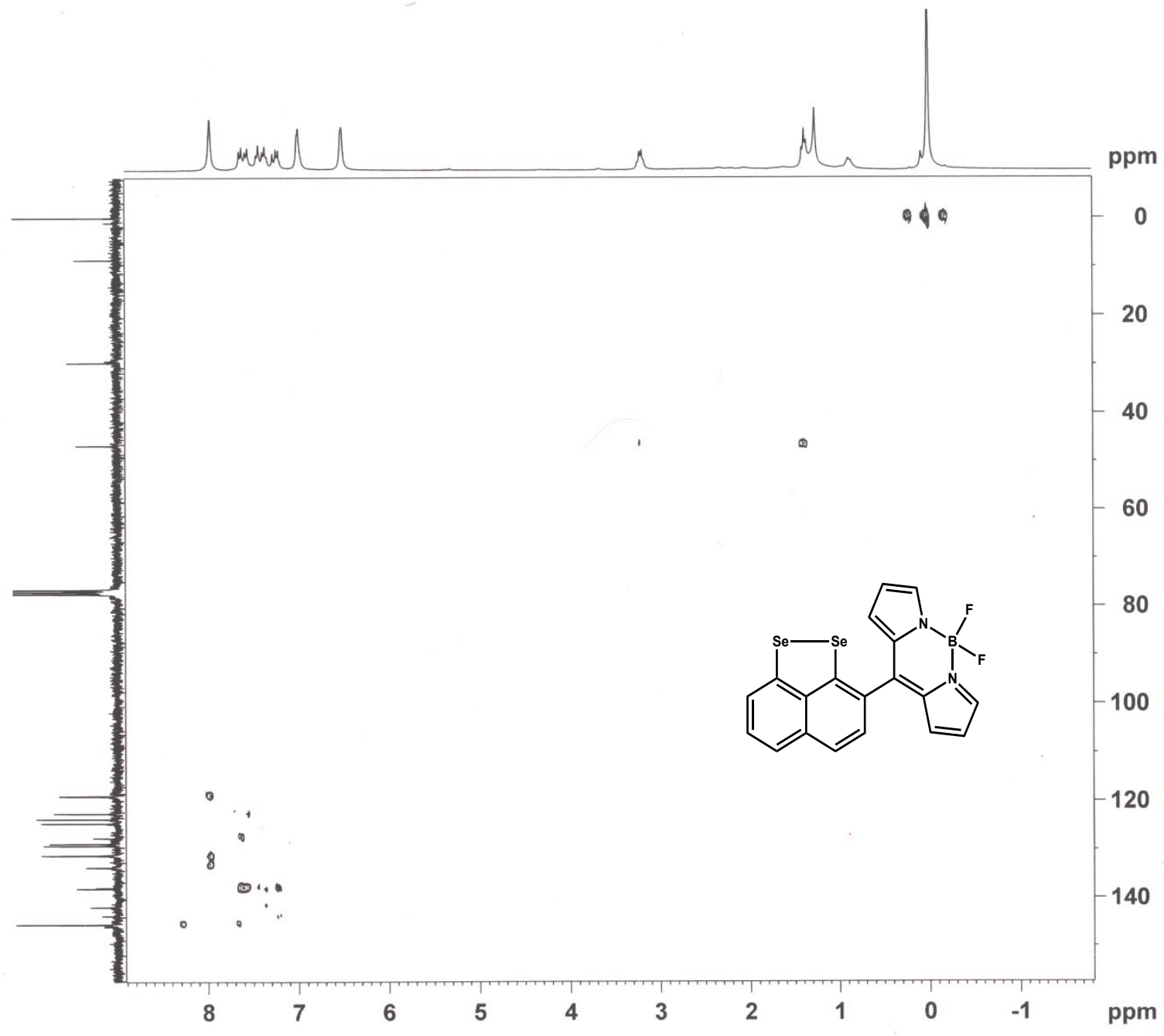

Figure S18. ${ }^{1} \mathrm{H}-{ }^{13} \mathrm{C}$ HMBC NMR spectrum of 3. 


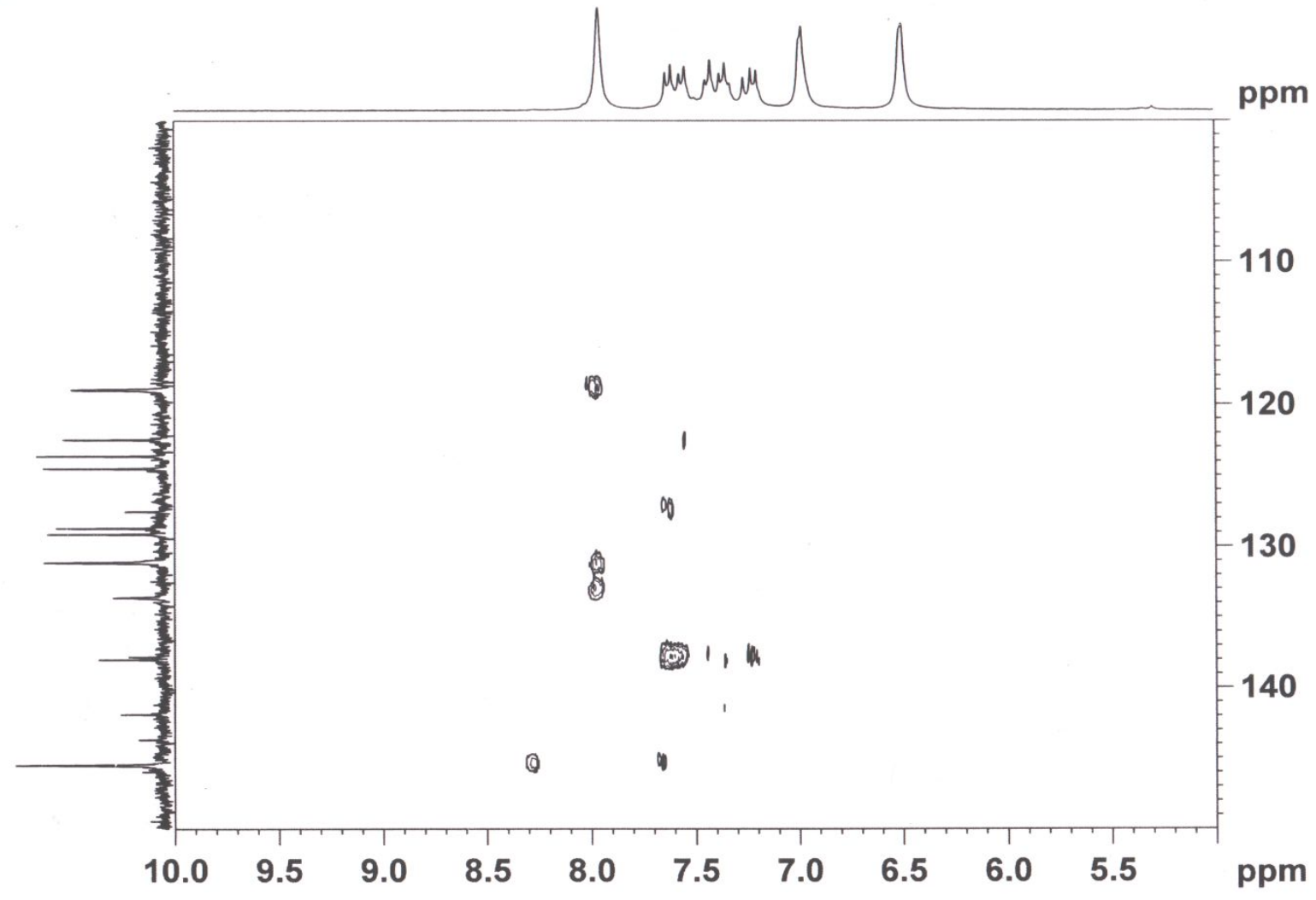

Figure S19. Expanded ${ }^{1} \mathrm{H}^{-13} \mathrm{C}$ HMBC NMR spectrum of 3. 


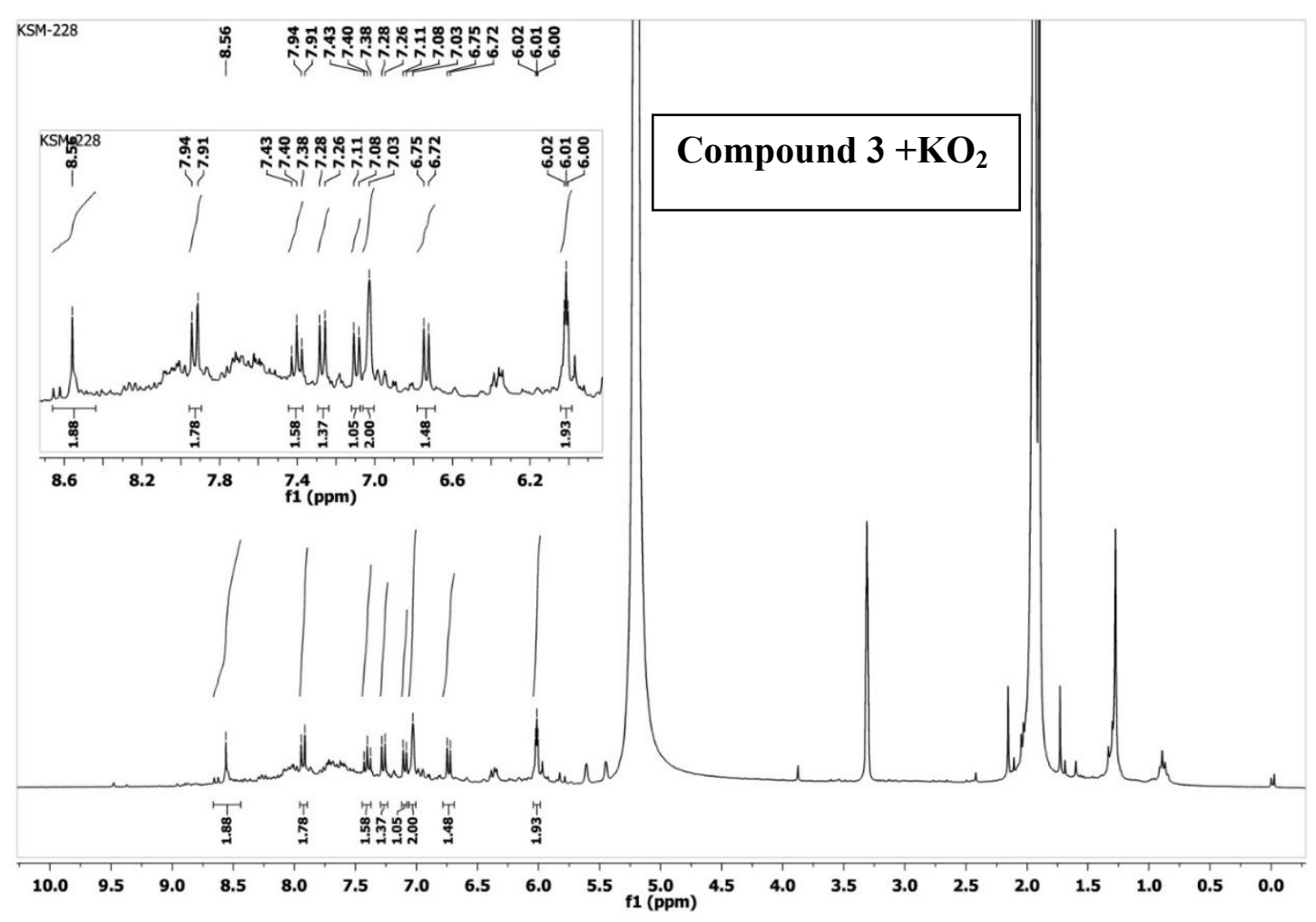

Figure S20. ${ }^{1} \mathrm{H}$ NMR spectrum of $\mathbf{3}+\mathrm{KO}_{2}$. 


\section{DEPARTMENT OF CHEMISTRY,I.I.T.(B)}

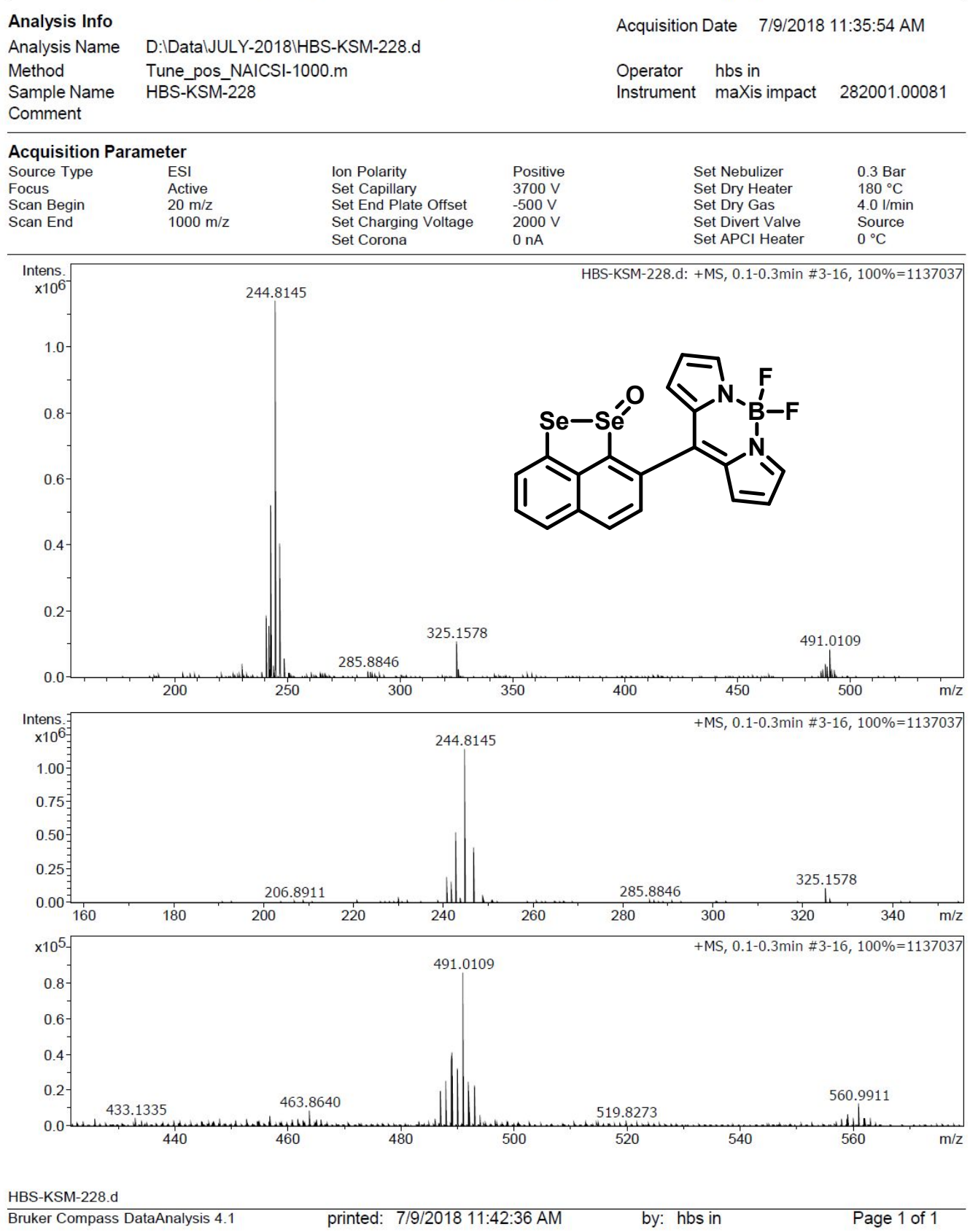

Figure S21. Mass spectrum of probe $\mathbf{3}+\mathrm{KO}_{2}$. 


\section{Photophysical study}

\section{Details for UV-vis and fluorescence measurements:}

The stock solutions of probe $3(20 \mu \mathrm{M})$ were prepared in DMSO-water $(\mathrm{v} / \mathrm{v}=30 / 70 ; 20 \mu \mathrm{M})$ and the $\operatorname{ROS}\left(\mathrm{O}_{2}{ }^{-}, \mathrm{H}_{2} \mathrm{O}_{2},{ }^{t} \mathrm{BuOOH},{ }^{-} \mathrm{OCl},{ }^{\circ} \mathrm{OH}\right.$ and $\left.{ }^{t} \mathrm{BuO} \mathrm{O}^{\circ}\right) 0.1 \mathrm{M}$ in water were prepared. The bio-thiols (L-cysteine, glutathione, D-L-homocysteine and N-acetyl-L-cysteine) were prepared as $0.1 \mathrm{M}$ solution in water. The $\lambda_{\max }$ absorption for probe 3 was $506 \mathrm{~nm}$ and the $\lambda_{\max }$ emission was $521 \mathrm{~nm}$. The graphs were plotted using Origin 8.

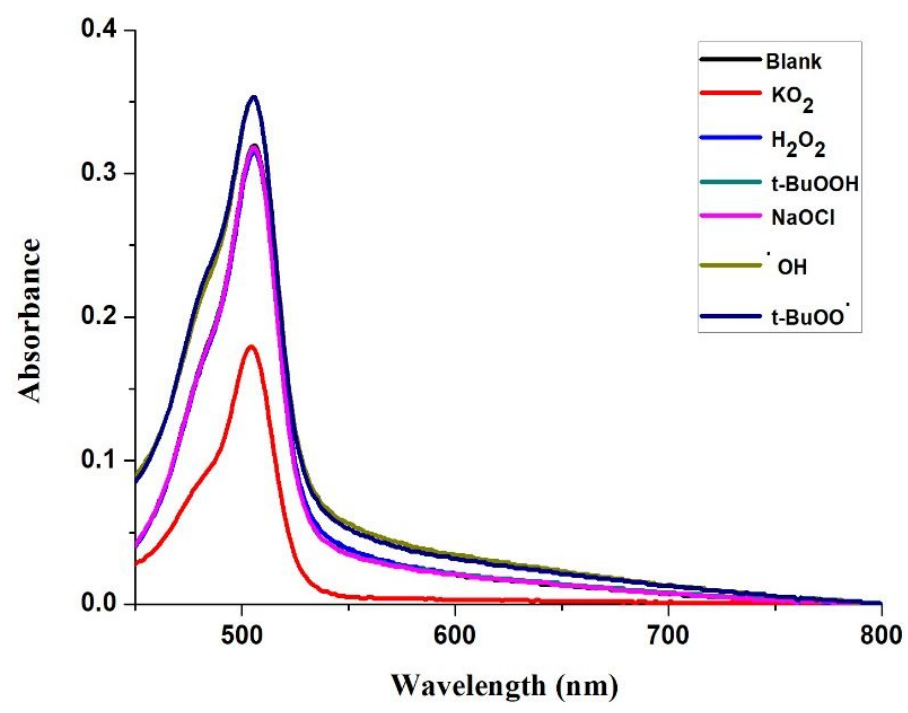

Figure S22. UV-vis spectral changes of probe $(20 \mu \mathrm{M}$, DMSO/water : v/v $=30 / 70)$ with $\operatorname{ROS}\left(\mathrm{O}_{2}{ }^{\circ}, \mathrm{H}_{2} \mathrm{O}_{2},{ }^{\mathrm{t}} \mathrm{BuOOH},-\mathrm{OCl},{ }^{\circ} \mathrm{OH},{ }^{\mathrm{t}} \mathrm{BuO}{ }^{\bullet}\right)$ (33.3 equivalent) incubated for 15 minutes at RT $\left(\lambda_{\max }=506 \mathrm{~nm}\right)$. 


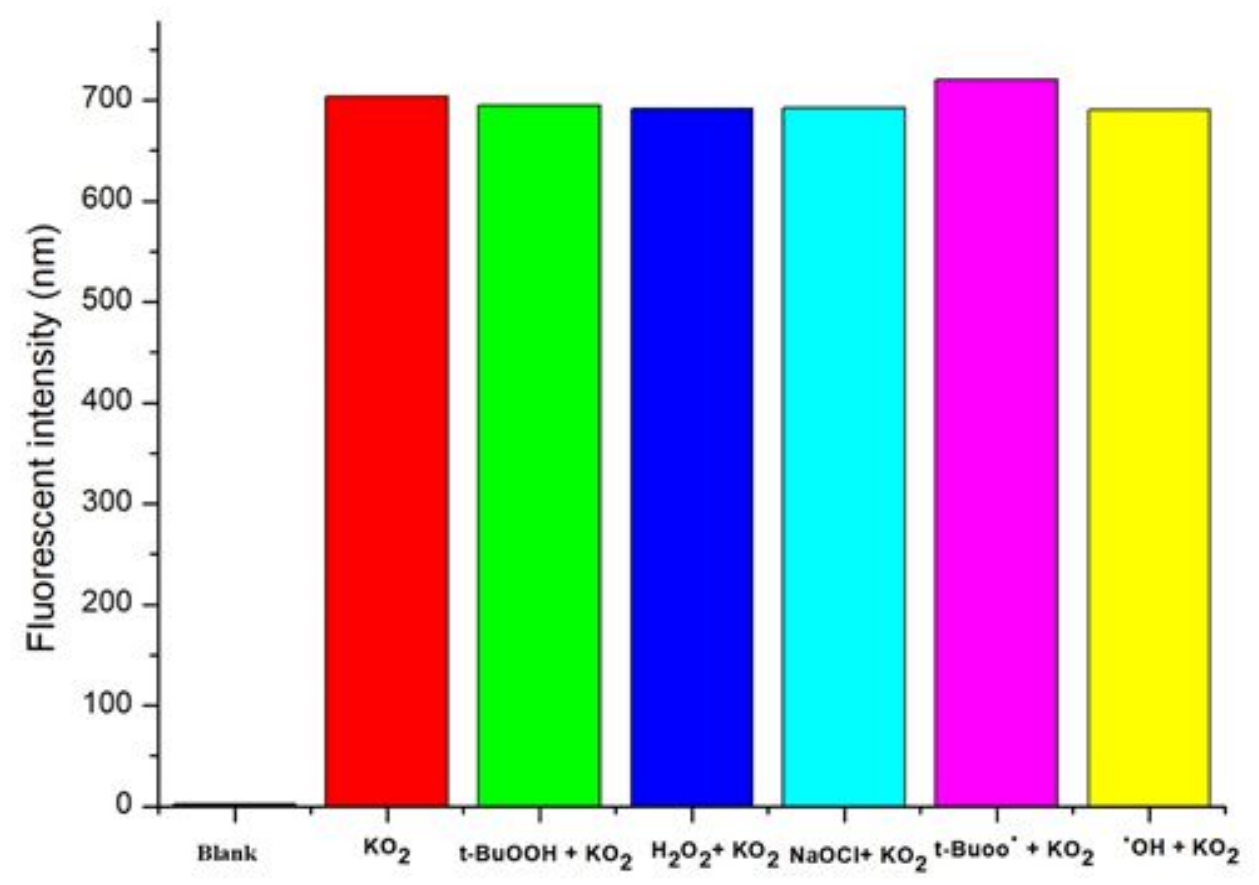

Figure S23. Fluorescence spectra of compound 3(20 $\mu \mathrm{M}$, DMSO/Water 30:70) and $\mathrm{KO}_{2}$ with other $\mathrm{ROS}\left({ }^{\mathrm{t}} \mathrm{BuHO}_{2}, \mathrm{H}_{2} \mathrm{O}_{2},{ }^{-} \mathrm{OCl},{ }^{\mathrm{t}} \mathrm{BuO}{ }^{\bullet}\right.$ and $\left.{ }^{\circ} \mathrm{OH}\right)$ incubated for 15 minutes at $\mathrm{RT}\left(\lambda_{\mathrm{ex}}=506\right.$ $\mathrm{nm}$ and $\lambda_{\mathrm{em}}=521 \mathrm{~nm}$ ), slit width: $3 / 3 \mathrm{~nm}$.

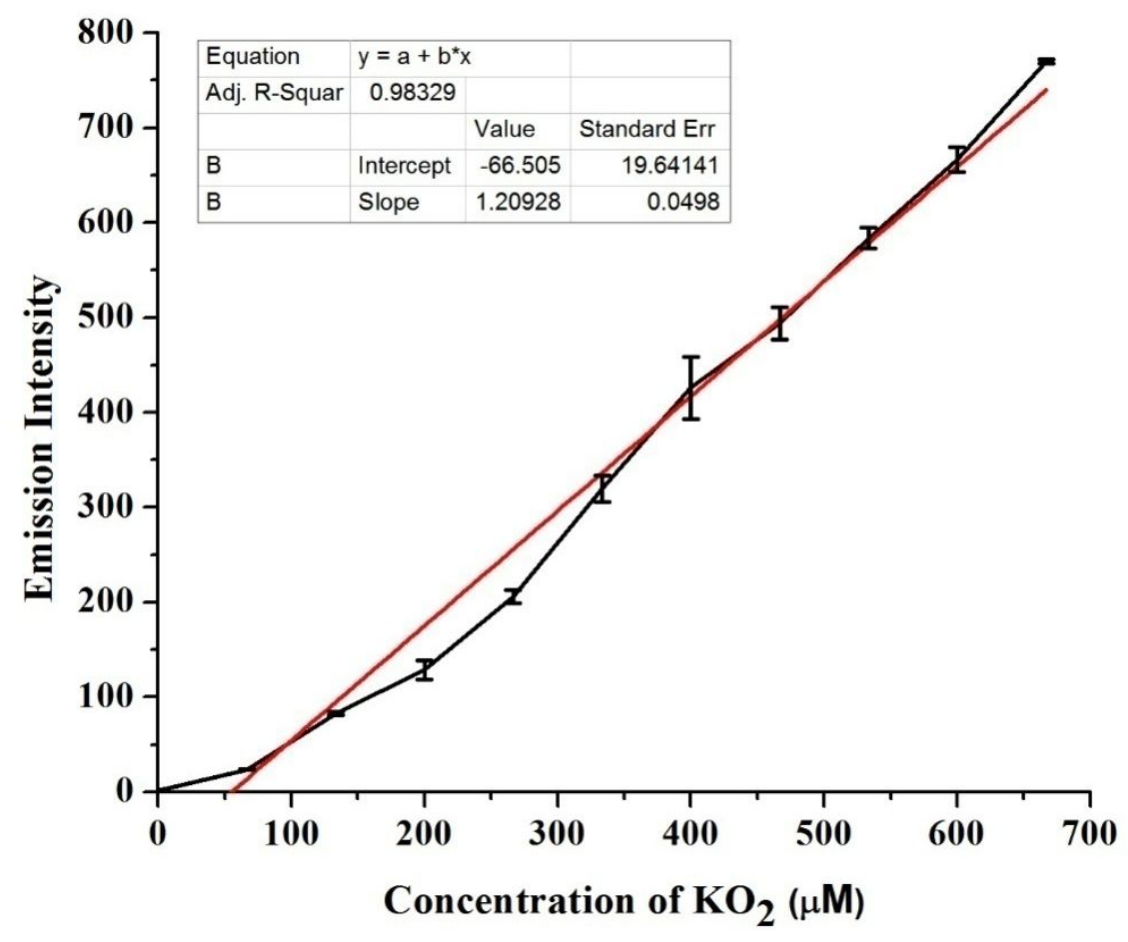


Figure S24. Plot for the calculation of limit of detection from the emission of the probe (20 $\mu \mathrm{M}, \mathrm{DMSO} /$ Water 30:70) with increasing concentration of $\mathrm{KO}_{2}(0-666.6 \mu \mathrm{M}$ in water), (average of three experiments) $\left(\lambda_{\mathrm{ex}}=506 \mathrm{~nm}\right.$ and $\left.\lambda_{\mathrm{em}}=521 \mathrm{~nm}\right)$; slit width: $3 / 3 \mathrm{~nm}$.

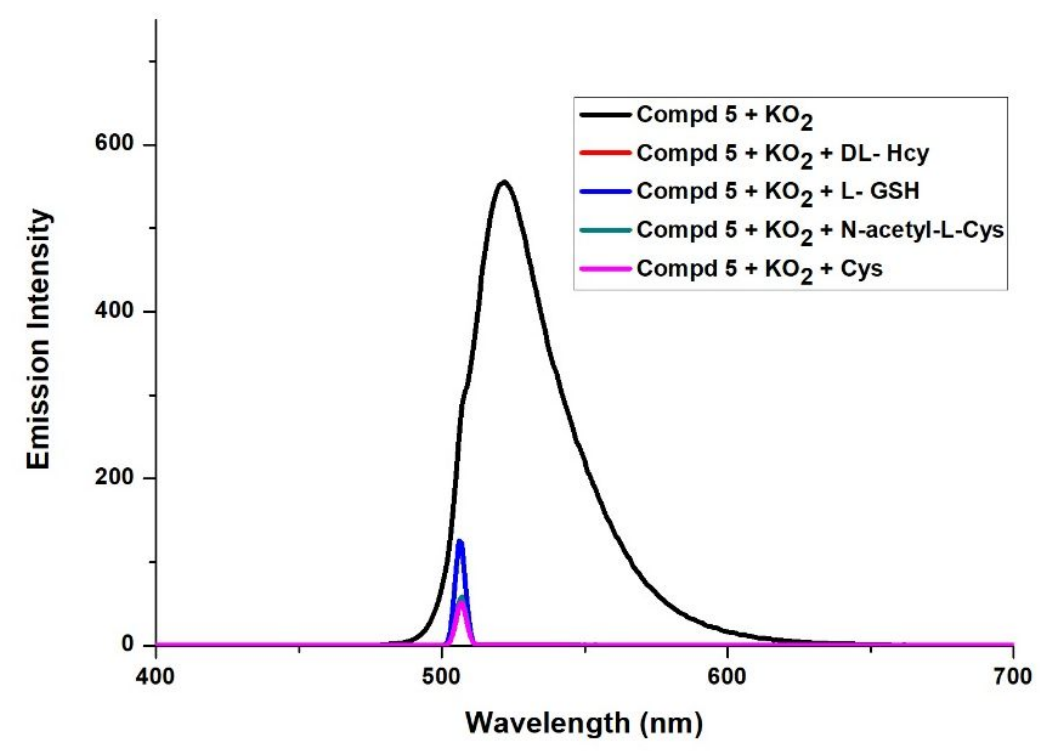

Figure S25. Fluorescence responses before and after addition of bio-thiols(glutathione, Nacetyl-L- cysteine, DL-homocysteine and L-cysteine) (33.3 equiv.) to the solution of compound 3(20 $\mu \mathrm{M}, \mathrm{DMSO} /$ water: v/v = 30/70)and superoxide (33.3 equiv) incubated for 15 $\min .\left(\lambda_{\mathrm{ex}}=506 \mathrm{~nm}\right.$ and $\left.\lambda_{\mathrm{em}}=521 \mathrm{~nm}\right)$; slit width: $3 / 3 \mathrm{~nm}$.

\section{Details of cell study}

To do the cell study MCF-7 cells were seeded in a 24 -well plate $\left(\sim 1 \times 10^{4}\right.$ cells per well $)$ in DMEM media on glass coverslips. The cells were incubated overnight at $37^{\circ} \mathrm{C}$ with $5 \% \mathrm{CO}_{2}$. The coverslips were mounted using DABCO mounting media and observed under Leica DMi8 microscope in DIC and in fluorescence mode. MCF-7 cell line without any treatment when observed under confocal fluorescence microscopy, we did not observed any fluorescence inside the cells.Phorbol-12-myristate-13-acetate (PMA) control study (without probe), no remarkable fluorescence inside the cells was observed.

MCF-7 cells were treated with $100 \mu \mathrm{M}$ concentration of probe $\mathbf{3}$, dissolved in DMSO. PMA $(1 \mu \mathrm{M})$ was added to induce ROS production. The cells were incubated for 1 hour and fixed with $4 \%$ para-formaldehyde for 20 minutes. We observed strong fluorescence signal inside the 
cells in the presence of probe 3 . These results confirmed the ability of the probe for selective detection of superoxide inside the cells. 